\title{
Hubungan Merokok dan Kadar Leukosit pada Perokok Kronik
}

\author{
${ }^{1}$ Gabrielle E. Sirih \\ ${ }^{2}$ Joice N. Engka \\ ${ }^{2}$ Sylvia R. Marunduh
}

\author{
${ }^{1}$ Program Studi Pendidikan Dokter Fakultas Kedokteran Universitas Sam Ratulangi Manado \\ ${ }^{2}$ Departemen Fisiologi Fakultas Kedokteran Universitas Sam Ratulangi \\ Email: gabrielleecaristysirih@gmail.com
}

\begin{abstract}
Smoking is one of the leading causes of health problems in the world. The World Health Organization (WHO) shows that Indonesia is in third place with the largest number of smokers that reached 146.860.000 inhabitants. In North Sulawesi, almost one-third of the population aged $\geq 10$ years are chronic active smokers with the average number of cigarettes smoked 10 cigarettes per day. WHO classifies smokers into mild, moderate, and severe smokers. Some studies found that cigarette smoking could affect the values of various blood parameters. This study was aimed to determine whether there was a relationship between chronic smoking and leukocyte levels in adult smokers. This was an analytical descriptive study with a cross-sectional design conducted on 30 students of Mechanical Engineering Faculty of Sam Ratulangi University Manado. Data were statistically analyzed with KruskalWallis test on leukocyte, basophil, eosinophil, stem neutrophil, and monocyte meanwhile the One Way Anova on neutrophil segments, and lymphocytes. The Kruskal-Wallis test and the One Way Anova obtained all $P$ values $>0.05$. Respondents had average leukocyte counts and normal white blood cell differential counts. Conclusion: There was no significant relationship between smoking andd leukocyte levels in chronic smokers.
\end{abstract}

Keywords: chronic smokers, leukocyte level, white blood cell differential count

\begin{abstract}
Abstrak: Merokok merupakan salah satu penyebab masalah kesehatan terbanyak di dunia. World Health Organization (WHO) menyebutkan Indonesia berada pada urutan ketiga dengan jumlah perokok terbanyak yang mencapai 146.860 .000 jiwa. Untuk daerah Sulawesi Utara, hampir sepertiga penduduk berusia $\geq 10$ tahun merupakan perokok aktif kronik dengan rerata jumlah rokok yang dihisap 10 batang per hari. WHO menglasifikasikan perokok menjadi perokok ringan, sedang, dan berat. Beberapa penelitian melaporkan bahwa rokok dapat memengaruhi nilai dari berbagai parameter darah. Penelitian ini bertujuan untuk mengetahui apakah terdapat hubungan antara merokok dan kadar leukosit pada perokok kronik. Jenis penelitian ialah deskriptif analitik dengan desain potong lintang yang dilakukan pada 30 mahasiswa Jurusan Teknik Mesin Fakultas Teknik Universitas Sam Ratulangi Manado. Uji statistik Kruskal- Wallis dilakukan pada kadar leukosit, basofil, eosinofil, neutrofil batang, monosit sedangkan One Way Anova pada neutrofil segmen, dan limfosit. Baik pada uji Kruskal-Wallis maupun One Way Anova didapatkan semua nilai $P>0,05$. Responden memiliki rerata kadar leukosit dan hitung jenis leukosit yang normal. Simpulan: Tidak terdapat hubungan bermakna antara merokok dan kadar leukosit pada perokok kronik

Kata kunci: merokok kronik, kadar leukosit, hitung jenis leukosit
\end{abstract}

Perokok tersebar di seluruh dunia. jumlah perokok dunia berasal dari Sebanyak satu miliar laki-laki, dan 250 juta penduduk Asia dan Australia, 14\% perempuan dari seluruh kalangan di dunia penduduk Eropa Timur, $12 \%$ penduduk merupakan perokok aktif. Sebanyak 57\% Amerika , 9\% penduduk Eropa Barat, dan 
8\% penduduk Timur Tengah serta Afrika. Menurut The Tobacco Atlas, tercatat lebih dari sekitar 10 juta batang rokok yang dihisap setiap menit dalam setiap hari di seluruh dunia. 1,2

Dari jumlah perokok di dunia, sekitar 900 juta jiwa (84\%) tinggal di negaranegara berkembang; salah satunya di Indonesia. Badan Kesehatan Dunia (WHO) menyebutkan, Indonesia berada pada urutan ketiga dengan jumlah perokok terbanyak yang mencapai 146.860 .000 jiwa. ${ }^{3}$ Berdasarkan data Riskesdas tahun 2013, rata-rata jumlah batang rokok yang dihisap meningkat dari 12 batang perhari pada tahun 2007 menjadi 12,3 batang per hari pada tahun 2013. Untuk daerah Sulawesi Utara, secara umum hampir sepertiga penduduk berusia $\geq 10$ tahun merupakan perokok aktif dengan rerata jumlah rokok yang dihisap 10 batang per hari dengan presentase jumlah perokok terbesar terletak di Kabupaten Bolaang Mongondow (34\%), sedangkan persentase terendah di Kota Bitung (24,8\%). Di kota Manado sendiri persentase perokok berada di angka 30,5\% dari seluruh jumlah penduduk. ${ }^{4}$

WHO menglasifikasikan perokok atas tiga kategori menurut jumlah rokok yang dikonsumsi tiap harinya, yaitu ringan (1-10 batang ), sedang (11-19 batang ) dan berat (lebih dari sama dengan 20 batang). Perokok kronik sendiri adalah mereka yang merokok minimal 2 tahun tanpa henti selama hidupnya. ${ }^{5-7}$

Merokok dapat menyebabkan timbulnya berbagai masalah kesehatan diantara nya yaitu penyakit jantung koroner, bronchitis, infeksi saluran napas bahkan bisa menyebabkan kanker paru. Asap rokok mengandung berbagai macam zat berbahaya diantaranya karbon monoksida, nikotin, dan tar yang memegang peranan besar sebagai sumber penyakit. Paparan asap rokok yang berkepanjangan menyebabkan reaksi inflamasi sistemik kronik yang menyebabkan cedera jaringan. ${ }^{8}$

Leukosit merupakan agen pertahanan tubuh utama terhadap infeksi yang bekerja lewat proses fagositosis dan juga berperan penting dalam proses imunitas terhadap cedera jaringan. Leukosit terdiri dari dua bagian besar yaitu granulosit yang terdiri dari tiga jenis sel yaitu neutrofil, eosinofil dan basofil yang bersama-sama dengan monosit berperan dalam fungsi fagositosis. Yang kedua yaitu agranulosit yang terdiri dari monosit dan limfosit. Limfosit berfungsi dalam proses imunitas. ${ }^{9,10}$ Penelitian ini bertujuan untuk mengetahui apakah terdapat hubungan antara merokok dan kadar leukosit pada perokok kronik.

\section{METODE PENELITIAN}

Jenis penelitian ini ialah deskriptif analitik dengan desain potong lintang. Penelitian dilaksanakan pada bulan September sampai November 2017, bertempat di Fakultas Teknik Universitas Sam Ratulangi Manado. Responden diambil dengan menggunakan teknik purposive sampling dengan jumlah sebanyak 30 orang yang memenuhi kriteria inklusi dan eksklusi.

Data penggunaan rokok diperoleh melalui kuesioner yang diisi oleh responden sebelumnya dalam lembaran informed consent. Pemeriksaan kadar leukosit diambil melalui darah vena oleh petugas laboratorium dan sampel darah diperiksa di Laboratorium Klinik dengan alat Micros 60 ABX. Data diolah menggunakan program pengolah data.

\section{HASIL PENELITIAN}

Berdasarkan usia, responden terbanyak berusia 19 tahun $(26,7 \%)$, dan tersedikit berusia 24 tahun $(6,7 \%)$.

Berdasarkan lamanya merokok, terbanyak ialah responden yang telah merokok selama 2-5 tahun dengan jumlah responden sebanyak 18 orang (60\%). Untuk usia awal mulai merokok terbanyak pada usia 11-15 tahun berjumlah 14 orang $(46,7 \%)$. Berdasarkan kategori WHO didapatkan jumlah responden terbanyak merupakan perokok sedang yang berjumlah 19 orang $(63,3 \%)$. Jenis rokok yang sering dikonsumsi responden ialah rokok biasa (non filter) yang berjumlah 20 orang $(66,7 \%)$ (Tabel 3). 
Tabel 1. Karakteristik dasar responden berdasarkan usia

\begin{tabular}{ccc}
\hline $\begin{array}{c}\text { Usia } \\
\text { (tahun) }\end{array}$ & $\begin{array}{c}\text { Frekuensi } \\
\text { (orang) }\end{array}$ & $\begin{array}{c}\text { Persentase } \\
(\%)\end{array}$ \\
\hline 18 & 4 & 13,3 \\
19 & 8 & 26,7 \\
20 & 3 & 10 \\
21 & 5 & 16,7 \\
22 & 5 & 16,7 \\
23 & 3 & 10 \\
24 & 2 & 6,7 \\
Jumlah & 30 & 100 \\
\hline
\end{tabular}

Tabel 2. Karakteristik responden berdasarkan penggunaan rokok

\begin{tabular}{lccc}
\hline \multicolumn{2}{c}{ Parameter } & $\begin{array}{c}\text { Jumlah } \\
\text { (orang) }\end{array}$ & $\begin{array}{c}\text { Persentase } \\
(\%)\end{array}$ \\
\hline Lamanya & $2-5$ & 18 & 60 \\
merokok & $5-10$ & 11 & 36,6 \\
(tahun) & $\geq 10$ & 1 & 3,3 \\
\hline Usia & $6-10$ & 3 & 10 \\
pertama & $11-15$ & 14 & 46,7 \\
merokok & $\geq 16$ & 13 & 43,3 \\
(tahun) & & & \\
\hline Kategori & Ringan & 6 & 20 \\
WHO & Sedang & 19 & 63,3 \\
& Berat & 5 & 16,7 \\
\hline
\end{tabular}

Gambaran kadar dan hitung jenis leukosit pada responden dengan kategori perokok ringan, sedang dan berat memperlihatkan nilai rerata hitung jenis leukosit normal berdasarkan nilai rujukan yaitu untuk leukosit total normalnya 3,6 $11 \times 10^{3} / \mathrm{mm}^{3}$, basofil $0-1 \%$, eosinofil 1 $3 \%$, neutrofil batang 2-6\%, neutrofil segmen 50-70\%, limfosit 20-40\%, dan monosit 2-8\% (Tabel 4).

Tabel 3. Karakteristik responden berdasarkan jenis rokok yang dikonsumsi

\begin{tabular}{lcc}
\hline Jenis rokok & $\begin{array}{c}\text { Frekuensi } \\
\text { (orang) }\end{array}$ & $\begin{array}{c}\text { Persentase } \\
(\boldsymbol{\%})\end{array}$ \\
\hline Kretek & 1 & 3,3 \\
Biasa/Non filter & 20 & 66,7 \\
Kretek dan biasa & 9 & 30 \\
Jumlah & 30 & 100 \\
\hline
\end{tabular}

Berdasarkan uji Kruskal-Wallis didapatkan baik basofil, eosinofil, neutrofil batang, dan monosit memiliki nilai $P>0,05$ yang menunjukkan tidak terdapat hubungan bermakna antara perokok derajat ringan, sedang, dan berat dengan kadar leukosit maupun jumlah hitung jenis leukosit.

Berdasarkan uji One Way Anova didapatkan kadar neutrofil segmen dan limfosit memiliki nilai $P>0,05$ yang menunjukkan tidak terdapat hubungan bermakna antara perokok derajat ringan, sedang, berat terhadap jumlah neutrofil segmen dan limfosit.

Tabel 4. Karakteristik responden berdasarkan kadar leukosit

\begin{tabular}{lccc}
\hline Jenis leukosit $(\%)$ & \multicolumn{3}{c}{ Mean \pm SD } \\
\cline { 2 - 4 } & Perokok ringan & Perokok sedang & Perokok berat \\
\hline Leukosit umum $\left(10^{3}\right)$ & $8.73 \pm 2.468$ & $8,34 \pm 1,988$ & $8,82 \pm 2,583$ \\
Basofil & $0 \pm 0$ & $0 \pm 0$ & $0 \pm 0$ \\
Eosinofil & $0.33 \pm 0.816$ & $0,68 \pm 0,749$ & $0,20 \pm 0,447$ \\
Neutrofil batang & $1,67 \pm 1,506$ & $2,32 \pm 1,376$ & $2,40 \pm 0,894$ \\
Neutrofil segmen & $55,83 \pm 6,113$ & $56,63 \pm 6,094$ & $53,40 \pm 6,950$ \\
Limfosit & $37,17 \pm 5,565$ & $35,68 \pm 6,430$ & $39,00 \pm 6,745$ \\
Monosit & $5,00 \pm 1,265$ & $4,32 \pm 1,204$ & $5,00 \pm 1,000$ \\
\hline
\end{tabular}

\section{BAHASAN}

Dari pemeriksaan kadar leukosit total maupun hitung jenis leukosit didapatkan hasil kadar leukosit total, basofil, eosinofil, neutrofil batang, neutrofil segmen, limfosit dan monosit memiliki nilai sig berturutturut ialah $(P=0,972),(P=1,000),(P=$
0,244), $(P=0,462), \quad(P=0,640), \quad(P=0,684)$ dan $(P=0,409)$ dimana semua nilai $p$ $>0,05$. Hal ini menunjukkan bahwa tidak terdapat hubungan bermakna antara derajat merokok ringan, sedang, berat terhadap kadar leukosit yang didapatkan baik dari pemeriksaan total kadar leukosit maupun 
dari hitung jenis leukosit.

Hasil penelitan serupa dikemukakan oleh Martantya et al. ${ }^{11}$ yang menyatakan bahwa pada perokok rata-rata hitung jenis leukosit dalam batas normal kecuali neutrofil segmen yang mengalami peningkatan dan limfosit yang menurun. Penelitian serupa dikemukakan oleh Rumora et al. $^{7}$ yang melaporkan bahwa perokok yang menderita PPOK memiliki rerata hitung jenis basofil, eosinofil, neutrofil, limfosit, dan monosit yang normal. Shivanand et al. ${ }^{12}$ juga mendapatkan hasil yang selaraas yaitu tidak terdapat perbedaan bermakna pada hitung jenis leukosit antara perokok yang menderita PPOK dan orang normal yang tidak merokok.

Penelitian oleh Hansen ${ }^{13}$ dari Fakultas Kedokteran Universitas Diponegoro yang dilakukan terhadap 80 perokok aktif dan 20 perokok pasif di kalangan mahasiswa Universitas Diponegoro melaporkan bahwa tidak terdapat hubungan bermakna antara kadar leukosit total $(P=0,224)$, jumlah neutrofil batang $(P=0,944)$, limfosit $(P=$ $0,294)$, dan monosit $(P=0,229)$ terhadap perokok aktif maupun pasif namun terdapat hubungan bermakna terhadap jumlah neutrofil segmen $(P=0,16)$ dan eosinofil $(P=0,10)$ antara perokok aktif dan perokok pasif.

Terdapat juga beberapa penelitian lain yang mendapatkan hasil yang berbeda. Penelitian oleh Aula et al. $^{14}$ dari Department of Biology, College of Science, Salahaddin University Iraq terhadap perokok aktif usia 25-35 dan 36-45 tahun yang merokok minimal 10 batang selama 10 tahun di kota Erbil menunjukkan bahwa terdapat peningkatan kadar leukosit total, neutrofil, eosinofil, basofil, monosit, dan limfosit pada kedua kelompok usia namun untuk basofil tidak terdapat peningkatan bermakna pada kelompok usia 25-35 tahun.

Penelitan oleh Shipa et al. yang dilakukan terhadap 58 perokok dan 77 bukan perokok menyatakan bahwa terjadi peningkatan kadar leukosit total terhadap perokok dibanding yang bukan perokok bersamaan dengan meningkatnya limfosit. Didapat juga peningkatan leukosit yang bermakna sejalan dengan kenaikan intensitas merokok. ${ }^{15}$ Penelitan oleh Lakshmi et al. mengenai efek merokok terhadap parameter hematologi dan lipid yang dilakukan terhadap 40 orang perokok dan 40 orang bukan perokok berumur 2540 tahun juga mendapatkan hasil serupa yaitu terjadi peningkatan kadar hemoglobin, hematokrit, total hitung leukosit, kolesterol, trigliserida, LDL, VLDL, dan penurunan HDL. Untuk perokok berat yang merokok lebih dari 20 pak rokok sehari menunjukkan peningkatan yang sangat signifikan dari jumlah sel darah merah, kadar leukosit total, dan peningkatan jumlah neutrofil. $^{16}$

Terdapat beberapa faktor yang dapat memengaruhi kadar leukosit pada tiap individu, yakni : usia, jenis kelamin, asupan gizi, aktivitas fisik, riwayat penyakit yang diderita, kebiasaan merokok, konsumsi alkohol, obat-obatan, serta alat dan metode tes yang digunakan. Selain itu penentuan kriteria inklusi penelitian juga berpengaruh terhadap hasil penelitian.

Peneliti tidak meninjau lebih lanjut mengenai beberapa faktor yang dapat mempengaruhi kadar leukosit pada penelitian ini, seperti asupan gizi, derajat aktivitas fisik, riwayat penyakit yang diderita, dan gaya hidup contohnya alkohol dimana hal tersebut dapat mempengaruhi hasil dari kadar leukosit maupun hitung jenis leukosit responden.

Pada penelitian ini digunakan data primer berupa kuesioner untuk mendapatkan data konsumsi rokok dan pemeriksaan darah vena untuk melihat kadar leukosit. Data yang didapatkan dari kuesioner juga tergantung dari kejujuran responden serta pemahaman responden terhadap pertanyaan yang diajukan oleh peneliti. Selain itu terbatasnya jumlah sampel yang memenuhi kriteria inklusi dan eksklusi juga berpengaruh terhadap hasil penelitian.

\section{SIMPULAN}

Dari hasil penelitian dapat disimpulkan tidak terdapat hubungan antara merokok dengan kadar serta hitung jenis leukosit pada perokok kronik. 


\section{SARAN}

Perlu dilakukan penelitian lebih lanjut mengenai hubungan merokok dengan kadar leukosit total dan hitung jenis leukosit dengan jumlah sampel yang lebih besar dan sampel yang berasal dari jurusan lain yang ada di Fakultas Teknik.

Perlu diteliti faktor kebiasaan hidup seperti alkohol, serta riwayat aktivitas fisik, asupan gizi dan riwayat penyakit terdahulu yang merupakan salah satu faktor yang dapat mempengaruhi kadar leukosit pada perokok kronik.

Perlu dilakukan fungsi tes paru untuk mengetahui fungsi paru dari perokok.

\section{UCAPAN TERIMA KASIH}

Terima kasih kepada seluruh mahasiswa Jurusan Teknik Mesin Fakultas Teknik Universitas Sam Ratulangi Manado atas partisipasinya dan Laboratorium Klinik atas bantuan dan kerja samanya serta pihak lain yang terlibat dalam penyelesaian penelitian ini.

\section{DAFTAR PUSTAKA}

1. American Cancer Society and Vital Strategies. The Tobacco Atlas. 2014 [cited 2017 Agustus 11]. Available from:http://www.tobaccoatlas.org/topic/ci garette-use-globally/.

2. Kementrian Kesehatan Republik Indonesia. Infodatin Pusat Data dan Informasi Kementrian Kesehatan RI Perilaku Merokok Masyarakat Indonesia. 2013

3. Rachmawati IK. Manajemen Sumber Daya Manusia. Yogyakarta: Andi, 2008.

4. Badan Penelitian dan Pengembangan Kesehatan Kementrian Kesehatan RI. Laporan Hasil RISKESDAS Provinsi SULUT Tahun 2007. Jakarta : Badan Penelitian dan Pengembangan Kesehatan, 2007.

5. Okuyemi KS, Ahluwalia JS, Richter KP, Mayo MS, Resnicow K. Differences among African American light, moderate, and heavy smokers. Nicotine \& Tobacco Research. 2001;3:45-50.

6. Schutz S. Oxygen saturation monitoring by pulse oximetry (4th ed). USA: AACN procedure manual for critical care, 2011.

7. Rumora L, Milevoj L, Popovic-grle S, Barisic K, Grubisic TZ, Cepelak I. Reduction in peripheral leukocyte heat shock protein 27 and 70 expression in chronic obstructive pulmonary disease. CCACAA. 2008;81(1):73-80.

8. Jaya M. Pembunuh Berbahaya itu Bernama Rokok (1st ed). Yogyakarta: Rizma, 2009.

9. Guyton AC, Hall JE. Buku Ajar Fisiologi Kedokteran (12th ed). Jakarta: EGC, 2014.

10. Hoffbrand AV, Petit JE, Moss PAH. Kapita Selekta Hematologi (4th ed). Jakarta: EGC, 2005; p. 221, 295.

11. Martantya RS, Nasrul E, Basyar M. Gambaran hitung jenis leukosit pada pasien penyakit paru obstruktif kronik yang dirawat di RSUP Dr. M. Djamil Padang. Jurnal Kesehatan Andalas. 2014;3(2):217-20.

12. Shivanand KG, Manjunath ML, Das SK. A comparative study of blood leucocyte count in smokers with chronic obstructive pulmonary condition and non-smokers. IJBAR. 2012;3 (10):781-4.

13. Hansen. Perbedaan jumlah dan hitung jenis leukosit antara perokok aktif dan perokok pasif dikalangan mahasiswa Universitas Diponegoro Semarang [Skripsi]. Semarang: Universitas Diponegoro; 2003.

14. D Aula FA, Qadir FA. Effect of cigarette smoking on some immunological and hematological parameters in male smokers in Erbil City. Jordan Journal of Biological Science. 2012;6(2):159-66.

15. Santika E. Mengintip Kisah Dibalik Tembakau. Nasionalis Rakyat merdekanews Online. 2011. [cited 2017 Sept 3]. Available from: http://nrmnews.com/2011/12/01/houseof-sampoerna-mengintip-kisahdibaliktembkau.

16. Jacobs M. From the First to the Last Ash: The History, Economics and Hazards of Tobacco (2nd ed). Great Britain: Cambridge, 1997. 